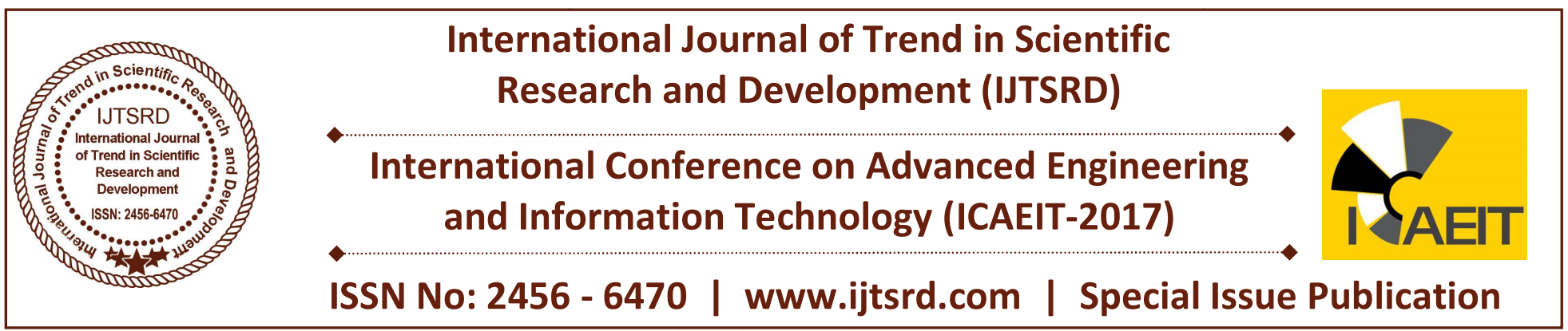

\title{
Review of Green Building Index (GBI) in Malaysia
}

\author{
Kamil M. ${ }^{1}$, Deepak T. J. ${ }^{2}$, Shanti. $\mathbf{M}^{1}$ \\ ${ }^{1}$ Student Faculty of Built Environment, Linton University College, Mantin, Negeri Sembilan, Malaysia \\ ${ }^{2}$ Associate Professor, Dean Faculty of Engineering and Technology, \\ Linton University College, Mantin, Negeri Sembilan, Malaysia
}

\section{ABSTRACT}

In recent years, global warming has been a major issue in every country all over the world which has yet to be resolved. World Development Indicator states, the amounts of carbon emission in Malaysia are increasing at an uncontrollable rate especially near the end of Year 2014 with a rate of 8 metric tons per capita. This rate lead to the implementation of "greener" approach towards industrial sector which includes the construction industry. Green Building Index (GBI) is the green rating tool recognized by the Malaysian construction industry to promote sustainability in the built environment. It is developed specifically for the Malaysian tropical climate by Persatuan Arkitek Malaysia (PAM) and Association of Consulting Engineers Malaysia (ACEM). Energy is becoming one of the most critical and important aspect to the nation, countries with high percentage of energy and resources is considered powerful as nowadays energy and resources of the country is key measurement for its power and development. The overall study indicated that there is an increase in sustainable construction in current Malaysian construction industry with respect to the GBI standards. This increase should be maintained to ensure all future buildings in Malaysia should follow the standards set by GBI.

Keywords: Malaysian Construction Industry, PAM, GBI, ACEM, Sustainability

\section{INTRODUCTION}

In recent years, global warming has been a major issue in every country all over the world which has yet to be resolved. In brief, global warming can be defined as the increase in temperature of the earth's atmosphere that is caused by the increase of particular gases, especially carbon dioxide (Oxford Advance Learner's Dictionary).

Report by the Intergovernmental Panel on Climate Change (IPCC), (2007), it was reported that over the past 100 years (1905- 2005), global temperature has increased by $0.74^{\circ} \mathrm{C}$. This figure might be small, but the impact to the world is huge. For example; changes in Arctic temperature that melts ice, change in wind patterns, and change in weather conditions, droughts, heavy rain, heat waves and natural disasters. It is also reported that, there is a $17 \mathrm{~cm}$ increase in sea water throughout the course of the 21 st Century.

Non-profitable Organizations conduct campaigns to educate society regarding global warming have finally reached Malaysia in these recent years by promoting "Green Ideas". Ideas such as basic recycling ethics, usage of biodegradable materials, planting trees, "No Plastic Bag Day" and other basic ideas are steadily progressing and implemented in the daily lives of the Malaysian citizens.

These campaigns and ideas are a start to reduce the effect of global warming but the real questions is what are the ideas that are contributed by themajor industrial sectors? As a Civil Engineer, the idea lies in the construction industry where the "Green Building" should be implemented.

Green Building focuses on increasing the efficiency of resource use; energy, water, and materials; while reducing building impact on human health and the environment during the building's lifecycle, through 
design, construction, operation, maintenance, and removal. Other famous terminologies for green building are zero energy building, low-energy building, natural building, sustainable building/architecture, and eco-house.

Launched on 21st May, 2009, the Green Building Index focuses on six main criteria which include;

1. Energy Efficiency

2. Indoor Environment Quality

3. Sustainable Site Planning \& Management

4. Materials \& Resources

5. Water Efficiency

6. Innovation

(Greenbuildingindex.org, 2009)

Chief Minister YAB Lim Guan Eng said; "Penang may impose the Green Building Index accreditation as a criterion for several upcoming development projects" (The Star, 26th July, 2009).

From this article, we can see that the GBI system will soon have a positive impact towards the Malaysian Construction Industry.

\section{OBJECTIVE OF THIS STUDY:}

\section{The specific objectives are:}

1. To identify the application of Green Building Index in Malaysia and its regulation in rating.

2. To identify the problems encountered and to differentiate the Green Building Index Classifications.

3. To find out whether current Malaysian construction industry practices sustainable construction based on Green Building Index.

A study done by Yale Centre for Environment Law \& Policy (2010) shows that the 2010 Environmental Performance Index (EPI), Malaysia is currently ranked 54th out of 163 countries with an overall EPI score of 65 . This was a major drop from the report shown in 2008 where Malaysia ranked 26th with an EPI score of 84. EPI is a performance indicator which consists of 10 categories covering both environmental public health and ecosystem vitality. This index system allows national government to scale their countries on how they establish environmental policy goals.

Currently, as of 2011, Malaysia consist of 28,728,607 populations an increase of $1.61 \%$ from previous years. This increase is due to the growth coming from development. The increase in growth rate and the combination of dramatic increase in per capita resources consumption will lead to serious social and environmental problems. With the national target of "Wawasan 2020" where Malaysia aims to become an industrial country, the problem will only worsen. The Malaysian community is using natural resources at an ever-fast rate with little regards to future generations to come.

Bashkin (2003) stated that there are three factors that contribute to excessive pressure on the environment and natural resources in Asian countries;

i. The increase of population in the last 35 years

ii. An increase in economic output in the last 20 years

iii. The persistence of poverty.

Bash kin (2003) also states that the environmental impact is caused by the growing discrimination between the rich and the poor. The rich and wealthy with their influences have access to a lifestyle which demands large amount of energy, resources and manufactured materials. While the poor are deprived of basic resources and are forced to make unsustainable use of resources to meet their survival needs.

The First Earth Summit - the United Nations Conference on Environmental and Development - at Rio de Janeiro in 1992 was held to bring awareness to the world regarding greenhouse gasses and ozone depletion. Since then Green building ratings were widely introduced in the 1990's with the development of BRE Environmental Assessment Method (BREEAM) introduced in the United Kingdom in 1990 and followed by Leadership in Energy and Environmental Design (LEED) introduced by the United States of America in 1996.

These tools act as guidance for engineers, architects, designers, builders, government bodies, building owners, developers and end users to understand the impact of each design choice and to provide a solution. Through this guideline, the final build product would perform better while at the same time reduce the impact towards the environment.

Consequently, not all green rating tools can be used throughout the world due to the difference in location and climate. Thus, since the First Earth Summit, Rio de Janeiro (1992) many different green rating tools 
International Journal of Trend in Scientific Research and Development (IJTSRD) | ISSN: 2456-647

have been introduced which concentrate within the temperate climate zones. Some include;

1. BRE Environmental Assessment Method (BREEAM), United Kingdom (1990)

2. Leadership in Energy and Environmental Design (LEED), United States of America (1996)

3. Comprehensive Assessment System for Built Environment Efficiency (CASBEE), Japan (2001)

4. Green Star (GREENSTAR), Australia (2003)

5. Green Mark (GREENMARK), Singapore (2005)

6. Green Building Index (GBI), Malaysia (2009)

7. Green Ship (GREENSHIP), Indonesia (2010)

According to Jerry Yudelson (2009), 40\% of the world carbon emission comes from buildings which are one of the culprits involved in the global warming phenomenon. Green building is a part of a response to further create awareness of the role that humans are society is causing the global climate change.

According to Chan SeongAun (2009) The GBI rating tool is created to be a standard form of measurement for a Malaysia building which contributes to environmental friendly and sustainable criteria. GBI is a recognized by the Malaysian government with regards to environmental leadership in development of green building in the construction industry. GBI helps to promote the integrated design and transform the built environment in reducing environmental impact and ensures that new buildings remain relevant in the future.

GBI Certification in Malaysia In Malaysia, the government has set up a framework which will be referred to as the "Green Building Index" for assessing the ecological design and performance of Malaysian buildings. The GBI rating system was established jointly by Malaysian Institute of Architects and the Association of Consulting Engineers Malaysia (ACEM). The motivation behind this inventory is to structure mindfulness among all the players in the development industry on the essentials of economic development. This framework has set up a progression of necessities which are thought to be ecological cordial amid the course of the life cycle of the building development.

\section{GBI CLASSIFICATION}

Four (4) classifications are given for the green building certifications to show the gradient of compliance with the requirements. The complete indexing is shown in table1.
Table 1: Green building index Classification (www.greenbuildingindex.com.my)

\begin{tabular}{|c|c|c|}
\hline Points & GB Ratings & Interference \\
\hline 86 & Platinum & Global excellence \\
\hline $76-85$ & Gold & National excellence \\
\hline $66-75$ & Silver & Excellent practice \\
\hline $50-75$ & Certified & Good practice \\
\hline
\end{tabular}

\section{GBI ADVANTAGES}

Four (4) main advantages are given for the green building certification.

1. Cost

2. Efficiency

3. Infrastructure

4. High Return of Investment

\section{Cost:}

The construction costs are the same as a standard building and sometime they cost a little bit more as they require special materials to be built. However, a regular building costs won't stop after its construction since money will always be spent on maintenance, renovation, operation or even demolition.

This doesn't mean that green buildings won't need maintenance, renovation, operation or even demolition as well, but being built of natural resources all that re-doing stuff will take ages till done as they are not damaged that fast hence, investing in green building is 10 times more profitable than standard ones.

\section{Efficiency:}

This here is divided to the following: -

A. Water efficiency:

Green buildings don't know the meaning of "wasted", they recycle rain water and grey water and use them for toilet flushing for instance.

\section{B. Energy Efficiency:}

These buildings save energy more than those built out of bricks. They only depend on all renewable energy resources such solar power, hydro-power and wind power which are used for heat and electricity and help improve the indoor air quality.

\section{Material Efficiency:}

Green buildings are built from natural, non-toxic and recycled materials that don't cost much and Ecofriendly such as bamboo, straw, recycled metal or concrete. 


\section{Preserving infrastructure:}

Being efficient in both energy and water supply, these buildings stretch the capacity of local infrastructure greatly.

\section{High ROI rates:}

Considering that these buildings are all natural, they have huge return on investment rates and properties in these buildings sell at high prices.

\section{GBI TOOLS}

Principally, when GBI was introduced in Malaysia there were very few tools available to certify the buildings. Now as of today there are twenty (20) tools available to grade almost all types of buildings. Each tool has significant elements in it to be assessed for certification.

1. GBI Non-Residential New Construction (NRNC) Tool

2. GBI Residential New Construction (RNC) Tool V1.0

3. GBI Residential New Construction (RNC) Tool $\mathrm{V} 2.0$

4. GBI Residential New Construction (RNC) Tool V3.0

5. GBI Non-Residential Existing Building (NREB) Tool

6. GBI NRNC:Data Centre Tool V1.0

7. GBI NREB:Data Centre Tool V1.0

8. GBI NRNC: Retail Tool V1.0

9. GBI NREB: Retail Tool V1.0

10. GBI Non-Residential New Construction (NRNC): Hotel Tool V1.0

11. GBI Non-Residential Existing Building (NREB): Hotel Tool V1.0

12. GBI Non-Residential New Construction (NRNC): Resort Tool V1.0

13. GBI Non-Residential Existing Building (NREB): Resort Tool V1.0

14. GBI Township Tool Version 1.01

15. GBI Industrial New Construction (INC) Tool V1.0

16. GBI Industrial Existing Building (IEB) Tool V1.0

17. GBI Interiors (ID) Tool V1.0

18. GBI Non-Residential New Construction (NRNC): Hospital Tool V1.0

19. GBI Non-Residential Existing Building (NREB): Hospital Tool V1.0

20. GBI Township Tool Version $2.0 * \mathrm{NEW}^{*}$

\section{BARRIERS IN IMPLEMENTING GREEN BUILDINGS}

Understanding the obstacles to green building development will help to find ways to promote the green building market (Chan et al., 2009). The lack of expertise knowledge in green building development creates an environment that lengthens development time frames (Choi, 2009). In addition, expert's knowledge is a key Factor to promote sustainable building (Miyatake, 1996), The level of general awareness about sustainable buildings and their benefits among the construction professionals is low (bellow moderate). According to Table 4 construction industry suffers lack of expertise's knowledge in terms of green building; consequently it will lead to a low level of implementation of green building concept in construction projects Based on Milad (2013), the barriers to green building are the most compared to other ones in the construction industry in Malaysia. There are 15 barriers and they are listed below;

1. Lack of building codes and regulations

2. Lack of incentives

3. Higher investment

4. Risk of investment

5. Higher final price

6. Lack of credit resources to cover initial cost

7. Lack of Public awareness

8. Lack of demand

9. Lack of strategy to promote GB

10. Lack of design and construction team

11. Lack of expertise

12. Lack of Professional knowledge

13. Lack of database and information

14. Lack of Technology

15. Lack of government support

In Malaysia, for evolving green building, government has just introduced two incentives such as tax exemption and stamp duty (ACEM, 2012). According to the finding the current incentives are not effective enough to encourage construction firms to enter green building development. Financial incentives are also notable to recoup the high upfront cost of green buildings and make it more affordable for construction companies.

In 2007, Bandy et al. have shown that that higher upfront cost (new design, technology and construction method) is the main weakness to green building development. Governmental financial incentives have essential rules to provide low risk and affordable financial resources for green developers in both 
commercial and residential sectors. Public awareness about green building has been an important component that led to high demand (Toronto green development standard, 2006).

\section{CONCLUSIONS}

Green buildings are now days the most commonly utilized structure of structural engineering. Building green buildings will be a vital center of building holders and even governments around the world. In Malaysia few world class Green Buildings have been constructed in recent years, yet the idea of green buildings for general masses is in outset stage.

In general, there are some matters that interrupt the implementation of Green Building. From this review, it is clear that, in Malaysia, the dynamic development of practice development by the legislature, nongovernmental associations and instruction, foundations in the recent years have demonstrated some respectable advancement in this field. There is a necessity to educate the public on GBI. Doing so will enable all the stakeholders to apply and implementation of green building construction.

\section{REFERENCES}

1. ACEM Directory (Association consulting engineers Malaysia). (2012). Retrieved from http://www.acem.com.my/index.php?option=com _content\&task $=$ view\&id=58\&Itemid $=1$

2. Bashkin, V.N; 2003. Environmental Chemistry: Asian Lessons. Netherlands: Kluwer Academic Publishers.

3. Bandy, R., Danckaert, C., Fetscher, G., Holmes, B., Gale, M., Mirsky, M. ... Stewart, S. (2007). Leed in upstate New York: an exploration of barriers, resources and strategies. USGBC New York Upstate chapter and environment finance center, EPA region 2, Maxwell capstone project.
4. BeritaAkitek, 2009. Forum \& Launch of Green Building Index. Kuala Lumpur, Malaysia: PertubuhanAkitek Malaysia.

5. BeritaAkitek, 2009. Green Design Forum and Preview of Green Building Index Malaysia. Kuala Lumpur, Malaysia: PertubuhanAkitek Malaysia.

6. BeritaAkitek, 2010. The Launch of Green Building Index "Non-Residential Existing Building” Rating. Kuala Lumpur, Malaysia: PertubuhanAkitek Malaysia.

7. Chan, E. W. W., Qian, K. Q., \& Lam, I. P. (2009). The market for green building in developed Asian cities: the perspectives of building designers. Energy Policy, 37, 3061-3070. http://dx.doi.org/10.1016/j.enpol.2009.03.057

8. Choi, C. (2009). Removing Market Barriers to Green Development: Principles and Action Projects to Promote Widespread Adoption of Green Development Practices. JOSRE, 1(1), 107138.

9. Jerry Yudelson, 2007. Green Building A to Z. Canada: New Society Publishers

10. Toronto green development standard report. (2006). Retrieved from http://www.toronto.ca/planning/environment/gree ndevelopment.htm

11. Miyatake, Y. (1996). Technology development and sustainable construction. Journal of Management in Engineering, 12(4), 23-27. http://dx.doi.org/10.1061/(ASCE)0742597X(1996)12:4(23)

12. IPCC Fourth Assessment Report (AR4). Geneva, Switzerland. 2007

13. Green Building Index , Malaysia http://greenbuildingindex.org.2009 